8-15-2016

\title{
Reform Has Only Just Begun
}

Nick Turkal

Follow this and additional works at: https://aah.org/jpcrr

Part of the Health and Medical Administration Commons, and the Public Health Commons

\section{Recommended Citation}

Turkal N. Reform has only just begun. J Patient Cent Res Rev. 2016;3:123-4. doi: 10.17294/

2330-0698.1259

Published quarterly by Midwest-based health system Advocate Aurora Health and indexed in PubMed Central, the Journal of Patient-Centered Research and Reviews (JPCRR) is an open access, peer-reviewed medical journal focused on disseminating scholarly works devoted to improving patient-centered care practices, health outcomes, and the patient experience. 


\title{
Reform Has Only Just Begun
}

\author{
Nick Turkal, MD | Editorial \\ Aurora Health Care, Milwaukee, WI
}

Just for a moment, let's set aside last year's Supreme Court decision $^{1}$ on the Affordable Care Act, ${ }^{2}$ the talk about a presidential legacy and the political backand-forth that accompanies major events these days. Because when it comes to really improving health care, we've only just begun.

Certainly, the Affordable Care Act has made strides in providing important additional and affordable insurance coverage for millions of Americans and has initiated other steps toward payment reform and helping Americans be and stay well. It also has helped to make Americans better educated consumers of health care. But for an industry that is still largely unsustainable in terms of its macroeconomics, one that is slow to change and too often inwardly focused, how do we institute true and lasting reform?

How do we transform the American health care infrastructure into a cost-effective, value-based, person-centered sector whose goal is no longer "sick care" but helping people live well?

To begin to answer this important question, I always return to my roots as a family doctor. I have had the unique privilege of caring for individuals and families for over 30 years, while also having the opportunity to enhance care for many of the communities of Wisconsin and Illinois as the CEO of a major health system. But the real roots of my career and many of my beliefs are still rooted in my early experience as a family physician in a rural Illinois community.

About a year into practice in this small town, I discovered some ugly facts about health care in the United States:

Correspondence: Nick Turkal, MD, Aurora Health Care, 750 W. Virginia St., P.O. Box 341880, Milwaukee, WI, 53234, Email: nick.turkal@aurora.org
- We are not adequately training physicians to address all of the needs of people and communities.

- We have had a view of health care that is reductionist versus holistic, meaning that, from a clinical perspective, we too often see only the component parts of a person or a disease or condition instead of the person as a whole.

- We have failed to adequately apply knowledge from other industries or from health care in other countries.

- In essence, we have designed a system to get precisely the outcomes we have today - one that is too expensive, purveying sick care rather than wellness, with incentives that are backward to desired outcomes, generating less than satisfied but still demanding consumers.

\section{Steps in the Right Direction}

None of this implies that we have not made progress. Much of what is better in health care today has evolved rather quickly and has been enhanced by technology. Sophisticated technology now provides physicians with some very effective diagnostic tools that we could not have imagined only a short time ago.

Electronic health records are proving to be a great enabler of better accuracy and fewer errors in medications and care protocols. ${ }^{3}$ Cancer care is dramatically better than a generation ago. ${ }^{4}$ For most diseases and conditions, there are more available medications and treatment modes. Integrated care systems, when they are properly designed and work for people, are demonstrating higher care quality and lower cost of care to communities. ${ }^{5-7}$ And let's be optimistic. It's taken two generations to get to the state we are in. It will take a number of years to reshape this industry.

\section{What Comes Next?}

First, quality is paramount. When we enhance quality and provide the right care the first time, outcomes are better and costs literally melt away. 
The next important step is to establish the right incentives for change. Today, we have better data than in the days of HMOs and capitation - not inherently bad concepts, but data-starved at the time. Providers today, armed with this data, are willing to take on risk, place more emphasis on outcomes and refocus our industry on wellness and prevention rather than sick care.

Only time will tell if pilot programs in this vein are successful and sustainable, but at the very least, these efforts are moving us from a payment system that emphasizes volume over value, from payment for each test and touch point to payment for the overall wellbeing of a person and a community.

We need effective partnership. No single party can do this alone. Health insurers must share more data and more risk. Employers need to refocus their sponsored health plans to incentivize individual health and wellness. Deductibles and copays in health plans cannot be so high as to inhibit people from preventive care. Government plans such as Medicare and Medicaid need to dramatically accelerate enhanced payment for quality. Providers must navigate a mixed model of fee-for-service and value-based payments. All of this is possible, and is in fact being tested in various ways around the country. But we all need to agree on where we are going.

We need people to take more accountability for their role in staying healthy. We need a true partnership between health care professionals and the people they care for. In terms of public health, we have mixed results. While smoking rates are falling, obesity is still a major problem in our country. And we have significant health disparities in underserved communities.

The consumer is king and queen. We need to listen to patients and treat them as real consumers, giving them options for their care that will include enhanced technologies such as telehealth.
We must also attack cost, but in thoughtful ways.

As incentives change to value-based care, there will be multiple opportunities to avoid costs in health care. But there needs to be a global discussion about what we pay for as a society and what has real value for those we serve. In areas where we know our costs are higher than in other countries but our outcomes are not better, we need to ask why.

The 2016 presidential election provides an excellent opportunity for candidates to take a thoughtful, balanced, comprehensive and collaborative view on how to continue reform. The choice is ours. Let's not let it slip away.

\section{Disclosure}

Dr. Turkal is president and CEO of Aurora Health Care, which publishes the Journal of Patient-Centered Research and Reviews.

\section{References}

1. King v. Burwell. 576 U.S. Supreme Court 14-114 (decided June 25, 2015). https://www.supremecourt.gov/ opinions/14pdf/14-114_qol1.pdf. Accessed July 15, 2016.

2. U.S. government. https://www.gpo.gov/fdsys/pkg/BILLS$111 \mathrm{hr} 3590 \mathrm{enr} / \mathrm{pdf} /$ BILLS-111hr3590enr.pdf. Accessed July $15,2016$.

3. Chaudhry B, Wang J, Wu S, et al. Systematic review: impact of health information technology on quality, efficiency, and costs of medical care. Ann Intern Med. 2006; 144:742-52. CrossRef

4. Siegel R, Ma J, Zou Z, Jemal, A. Cancer statistics, 2014. CA Cancer J Clin. 2014;64:9-29. CrossRef

5. Hwang W, Chang J, Laclair M, Paz H. Effects of integrated delivery system on cost and quality. Am J Manag Care. 2013 May 1;19(5):e175-84.

6. Weeks WB, Gottlieb DJ, Nyweide DE, et al. Higher health care quality and bigger savings found at large multispecialty medical groups. Health Aff (Millwood). 2010;29:991-7. CrossRef

7. Ramalho de Oliveira D, Brummel AR, Miller DB. Medication therapy management: 10 years of experience in a large integrated health care system. J Manag Care Pharm. 2010;16:185-95. CrossRef

(C) 2016 Aurora Health Care, Inc. 